\title{
ANALYSIS OF THE EFFECTS OF HYPOTHETICAL CHANGES IN GROUND-WATER WITHDRAWAL FROM THE FLORIDAN AQUIFER SYSTEM IN THE AREA OF GLYNN COUNTY, GEORGIA
}

By Robert B. Randolph and Richard E. Krause

\section{U.S. GEOLOGICAL SURVEY}

Water-Resources Investigations Report 90-4027

Prepared in cooperation with

CITY OF BRUNSWICK, GEORGIA

GLYNN COUNTY, GEORGIA

GEORGIA DEPARTMENT OF NATURAL RESOURCES

ENVIRONMENTAL PROTECTION DIVISION

GEORGIA GEOLOGIC SURVEY

COASTAL AREA PLANNING AND DEVELOPMENT COMMISSION

and the

U.S. ARMY CORPS OF ENGINEERS

Doraville, Georgia 


\title{
DEPARTMENT OF THE INTERIOR \\ MANUEL LUJAN, JR., Secretary
}

\author{
U.S. GEOLOGICAL SURVEY
}

Dallas L. Peck, Director

For additional information

write to:

District Chief

U.S. Geological Survey, WRD

6481 Peachtree Industrial Blvd.

Suite B

Doraville, GA 30360
Copies of this report can be purchased from:

U.S. Geological Survey

Books and Open-File Reports

Federal Center, Bldg. 810

Box 25425

Denver, CO 80225 


\section{CONTENTS}

Abstract 1

Introduction 2

Purpose and scope 2

Location and extent of study area $\mathbf{3}$

Previous investigations 3

Hydrogeologic setting $\mathbf{3}$

Aquifers and confining units $\mathbf{5}$

Surficial aquifer $\mathbf{5}$

Upper confining unit $\mathbf{5}$

Upper Floridan aquifer $\mathbf{6}$

Middle semiconfining unit and Lower Floridan aquifer $\quad 6$

Predevelopment ground-water flow system $\mathbf{8}$

Present-day ground-water flow system $\mathbf{1 1}$

Ground-water withdrawal 11

Potentiometric surface and water-level decline $\mathbf{1 1}$

Digital model of the aquifer system $\mathbf{1 4}$

Mathematical description and model assumptions $\quad 14$

Model design $\mathbf{1 5}$

Finite-difference grid $\mathbf{1 5}$

Model layers 15

Lateral boundary conditions $\mathbf{1 6}$

Hydrologic input data $\mathbf{1 6}$

Potentiometric surfaces and water-table altitudes $\quad 17$

Transmissivity $\mathbf{1 8}$

Leakance 18

Well discharge 19

Model calibration 19

Steady-state calibration of the predevelopment flow system

Steady-state calibration of the present-day flow system $\quad 21$

Model sensitivity to parameter changes 22

Effects of hypothetical changes in ground-water withdrawal $\quad 25$

Increased withdrawal on Colonels Island, Glynn County 25

Decreased withdrawal in Brunswick and increased withdrawal near Anguilla, Glynn County 27

Increased withdrawal near Meridian, McIntosh County 27

Summary and conclusions $\mathbf{3 0}$

References 31 


\section{ILLUSTRATIONS}

\section{[Plates are in pocket]}

Plate 1. Generalized hydrogeologic section of Glynn County, Georgia

Plates 2-3. Maps showing:

2. Comparison of potentiometric surfaces of the Upper Floridan aquifer in the area of Glynn County, Georgia

3. Distribution of transmissivity and pumpage for the Upper Floridan aquifer in the area of Glynn County, Georgia

Figures 1.-2. Maps showing:

1. Location of study area and digital model boundaries 4

2. Inferred faults and chloride concentrations in the Upper Floridan aquifer, Brunswick, Georgia area 7

Figure $3 . \quad$ Idealized section of the Floridan aquifer system under predevelopment conditions, from the northwestern to the southeastern part of the study area 9

4. Idealized section of the Floridan aquifer system under present conditions, from the northwestern to the southeastern part of the study area 12

5. Graph showing water-level fluctuation in well $34 \mathrm{H} 328$ completed in the Upper Floridan aquifer, Brunswick, Georgia, 1945-1986 13

Figures 6-8. Maps showing:

6. Simulated water-level decline caused by an increase in withdrawal of 10 million gallons per day on Colonels Island, Glynn County 26

7. Simulated water-level change caused by a decrease of 3 million gallons per day in withdrawal at Brunswick and an increase of 9 million gallons per day in withdrawal near Anguilla, Glynn County 28

8. Simulated water-level decline caused by a withdrawal of 10 million gallons per day near Meridian, McIntosh County

\section{TABLES}

Table 1. Simulated water budget, in million gallons per day, for predevelopment (1880) and present-day (May 1980 and May 1985) flow systems 10

2. Statistical summary of differences between measured and simulated water levels for the Upper Floridan aquifer 21

3. Statistical summary of differences between measured and simulated water levels for the Floridan aquifer system 21

4. Statistical results of the sensitivity analysis using the Upper Floridan aquifer water levels as the basis for comparison, May 1980 conditions 24

5. Statistical results of the sensitivity analysis using the Floridan aquifer system water levels as the basis for comparison, May 1980 conditions 24 


\section{CONVERSION FACTORS}

For those who may prefer to use metric (International System) units rather than inch-pound units, conversion factors for the terms used in this report are listed below.

to obtain metric units

\section{Length}

inch (in.)

25.4

foot (ft)

0.3048

mile (mi)

1.609

millimeter $(\mathrm{mm})$

meter $(\mathrm{m})$

kilometer $(\mathrm{km})$

Area

square mile $\left(\mathrm{mi}^{2}\right)$

square kilometer $\left(\mathrm{km}^{2}\right)$

\section{Volume}

gallon (gal)

3.785

liter (L)

\section{Flow}

inch per year

25.4

(in/yr)

cubic foot per second

0.02832

$\left(\mathrm{ft}^{3} / \mathrm{s}\right)$

million gallons per day

0.04381

(Mgal/d)

Transmissivity

foot squared per day

0.0929

meter squared per day

$\left(\mathrm{ft}^{2} / \mathrm{d}\right)$

$\left(\mathrm{m}^{2} / \mathrm{d}\right)$

Hydraulic Conductivity

foot per day

0.3048

meter per day

$(\mathrm{ft} / \mathrm{d})$

$(\mathrm{m} / \mathrm{d})$

millimeter per year $(\mathrm{mm} / \mathrm{yr})$

cubic meter per second $\left(\mathrm{m}^{3} / \mathrm{s}\right)$

cubic meter per second $\left(\mathrm{m}^{3} / \mathrm{s}\right)$

Sea Level: In this report "sea level" refers to the National Geodetic Vertical Datum of 1929 (NGVD of 1929)--a geodetic datum derived from a general adjustment of the first-order level nets of both the United States and Canada, formerly called "Sea Level Datum of 1929." 


\title{
ANALYSIS OF THE EFFECTS OF HYPOTHETICAL CHANGES \\ IN GROUND-WATER WITHDRAWAL FROM THE \\ FLORIDAN AQUIFER SYSTEM IN THE AREA \\ OF GLYNN COUNTY, GEORGIA
}

\author{
By
}

Robert B. Randolph and Richard E. Krause

\begin{abstract}
The Upper Floridan aquifer in the area of Glynn County, Georgia is highly productive and is the major source of water for most users. During 1985, ground-water withdrawal from the aquifer in the study area was about 260 million gallons per day. A large withdrawal in a small area resulted in localized saltwater intrusion. This indicated the need for improvement in the definition of the flow system and an effective tool for management of the resource. Improvement in the definition of the flow system and development of such a tool was accomplished with the design of a detailed digital model of the ground-water flow system in the Glynn County area.

A three-dimensional, finite-difference, ground-water flow model developed for a subregion of the Floridan Regional Aquifer-System Analysis project was used as a basis for the development of a refined flow model of the Glynn County area. The Glynn County model covers an area of 6,080 square miles.

The refined grid of the Glynn County model is aligned with the coarse grid of the regional model and each node is a division of the coarse-grid nodes. The refined grid is variably spaced; the smallest nodes and the greatest detail are in the areas of large groundwater withdrawal and increasing saltwater intrusion. Boundary flows for the Glynn County model are derived from the large-scale regional model.

The Glynn County model provides a useful tool to analyze the effects of increased ground-water withdrawal that are expected to accompany projected increases in population and industrial water demands. Simulated effects of various withdrawal alternatives on the ground-water flow system can then be compared to determine the most appropriate development alternatives.

A hypothetical increase of 9 million gallons per day in ground-water withdrawal northwest of the city of Brunswick and a decrease of 3 million gallons per day in withdrawal at the center of Brunswick were used to represent hypothetical movement of the municipal supply source away from the area experiencing water-quality problems. A projected increase in demand was included in the simulation. Simulation of this change in withdrawal indicated slightly higher water levels (less than 1 foot) at the center of Brunswick where water-quality problems exist. The simulated maximum drawdown at the new pumping center was about 5 feet. Other hypothetical simulations are provided to illustrate the usefulness of the model as a management tool.
\end{abstract}




\section{INTRODUCTION}

The Upper Floridan aquifer is the major source of water supply in coastal Georgia. Development of this aquifer in the Glynn County area began more than 100 years ago. Withdrawal in Glynn County reached a peak of about 97 million gallons per day (Mgal/d) in 1980. Because of concerns about the upward migration of saltwater and the potential for contamination of the aquifer in the Brunswick, Ga., area, withdrawals were reduced, and in 1985, ground-water withdrawals totaled about $78 \mathrm{Mgal} / \mathrm{d}$. Increased demand on the aquifer system for large volumes of water in a relatively small area has resulted in a general decline in the potentiometric surface of the Upper Floridan aquifer, and in the Brunswick area, upward migration of water having high concentrations of chloride (as high as 33,000 $\mathrm{mg} / \mathrm{L}$ ) in underlying water-bearing strata).

As part of a continuing program of water-resources investigations in Georgia, the U.S. Geological Survey in cooperation with the city of Brunswick; Glynn County; the State of Georgia, Department of Natural Resources, Environmental Protection Division, Georgia Geologic Survey; the Coastal Area Planning and Development Commission; and the U.S. Army Corps of Engineers, Savannah District, developed a digital model of the ground-water system in the Glynn County area. This model, herein referred to as the Glynn County model, was subsequently used to evaluate possible resource-management alternatives to meet increasing demands on the aquifer system.

The Glynn County model is a refinement of a recently developed, large-scale, ground-water flow model of the Floridan aquifer system in southeastern Georgia and adjacent parts of South Carolina and Florida. The large-scale model, which was developed as part of the Floridan Regional Aquifer-System Analysis (RASA) study (Krause and Randolph, 1989) was useful for examining regional flow systems. Because of the coarse grid size (16 $\mathrm{mi}^{2}$ blocks), however, the RASA model is not suitable for simulating the effects of small changes in stress in local areas where there are large hydraulic variations over short distances.

The detail required to evaluate the effects of changes in ground-water withdrawal on the local flow system of the Upper Floridan aquifer resulted in the development of the Glynn County model. This model is designed to provide the greatest detail in areas where ground-water withdrawal is greatest and saltwater intrusion is occurring. The design allows for greater definition of small differences in water levels resulting from changes in the distribution of ground-water withdrawal.

\section{Purpose and Scope}

This report describes the development and examples of application of a threedimensional, ground-water flow model of the Floridan aquifer system in the area of Glynn County, Ga. The model can be used to evaluate the effects of various ground-water withdrawal alternatives on ground-water levels in areas where the occurrence of or potential for saltwater intrusion limits the availability of freshwater supplies.

The hydrogeologic framework and the ground-water flow regime of the Floridan aquifer system in the area is described briefly and the aquifer characteristics used in the construction of the model are defined. Boundary conditions, model-construction methods, and assumptions and limitations to the model are described. 
Development and calibration of the Glynn County model required coupling it with the RASA model to provide flows along the model boundaries for each flow condition. The model then was calibrated against predevelopment (1880) and May 1980 conditions. The Glynn County model is used in this study to evaluate the effects on the flow system of hypothetical changes in ground-water withdrawal. Management scenarios of future watersupply alternatives were developed by the U.S. Army Corps of Engineers. The effects of these alternatives on the ground-water flow system are simulated and comparisons are made to determine the relative value of each development scenario.

\section{Location and Extent of Study Area}

The principal areas of interest in the study area include all the major areas of ground-water development within the Floridan aquifer system in Glynn County, Ga. The emphasis of the study is on Glynn County, but surrounding counties in Georgia and extreme northeast Florida also are included for digital modeling purposes (fig. 1). The study covers a total area of about $6,100 \mathrm{mi}^{2}$, of which about $2,000 \mathrm{mi}^{2}$ are offshore. Glynn County covers an area of about $450 \mathrm{mi}^{2}$.

\section{Previous Investigations}

The hydrogeology of the Floridan aquifer system in the coastal area from Savannah, Ga., to Jacksonville, Fla., has been studied extensively over the past two decades. Among the more recent and comprehensive studies that have included the Glynn County area are those by Wait and Gregg (1973), Gregg and Zimmerman (1974), Randolph and others (1985), Krause and Randolph (1989), Clarke and others (1990), and Maslia and Prowell (1990). Simulation results of the Floridan aquifer system in Glynn County and adjacent areas have been discussed previously in Krause and Counts (1975), Krause (1982), and Krause and Randolph (1989).

\section{HYDROGEOLOGIC SETTING}

The Floridan aquifer system is a near-vertically continuous carbonate sequence that includes consolidated marine limestone and dolomite, and lesser amounts of evaporite, clay, sand, and marl. Although the aquifer system is a composite of several lithostratigraphic and chronostratigraphic units that have similar hydraulic characteristics, the number and the ages of the units that make up the system differ throughout the study area. The Floridan aquifer system thickens from about $700 \mathrm{ft}$ in the northern part of the study area to more than 2,000 ft downdip in Glynn and Camden Counties, Ga., and in Nassau County, Fla. Locally, in the southeastern part of Glynn County, the aquifer system is more than 2,600 ft thick (plate 1). A detailed geologic description of the Floridan aquifer system is given in Krause and Randolph (1989).

Throughout most of the study area, the Floridan aquifer system generally can be separated into two permeable, water-bearing zones---the Upper and the Lower Floridan aquifers. From the Glynn County area south, a third permeable zone has been identified, the Fernandina permeable zone (Krause and Randolph, 1989), which is in the lower part of the Lower Floridan aquifer. 


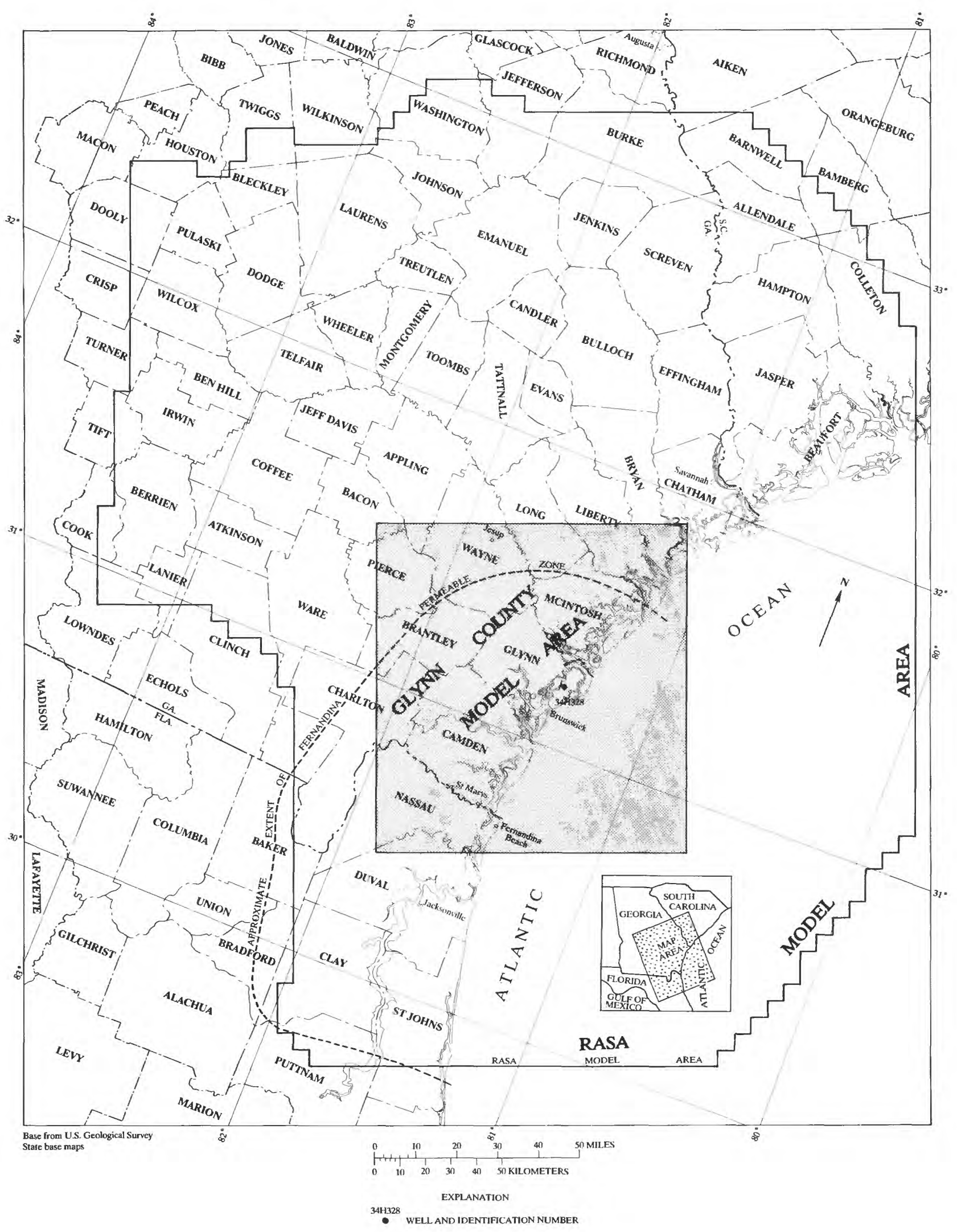

Figure 1.--Location of study area and digital model boundaries. 


\section{Aquifers and Confining Units}

Hydrogeologic units conceptualized for simulation are, in descending order: the surficial aquifer, the upper confining unit, the Upper Floridan aquifer, the middle semiconfining unit, and the Lower Floridan aquifer, which includes in its lower part, the lower semiconfining unit and the Fernandina permeable zone (Krause and Randolph, 1989, table 3).

\section{Surficial aquifer}

The surficial aquifer consists of unconsolidated, fine to very coarse, well-sorted postMiocene sand and is present throughout the study area. Interbedded with the well-sorted sand are layers of poorly sorted sand and clayey silt. The thickness of the surficial aquifer ranges from about $100 \mathrm{ft}$ to more than $300 \mathrm{ft}$ within the study area. Due to the vertical and lateral variations in lithology, the transmissivity of the surficial aquifer is variable. Brown (1984) reported values ranging from $700 \mathrm{ft}^{2} / \mathrm{d}$ in Camden County to $1,000 \mathrm{ft}^{2} / \mathrm{d}$ in Nassau County, Fla. Transmissivity values measured in the Brunswick area range from less than $1,000 \mathrm{ft}^{2} / \mathrm{d}$ to more than $6,000 \mathrm{ft}^{2} / \mathrm{d}$ (Gregg and Zimmerman, 1974).

Water in the surficial aquifer is unconfined. Generally, the configuration of the water table is a subdued replica of the land surface. The water table is near land surface in low-lying areas, along streams, in marshes and swamps, and generally in areas along the coast. The water table also is near land surface in areas where the surficial aquifer contains beds of low-permeability material. The water table is lower in areas beneath topographic highs and where thick deposits of permeable material are present, such as the Pleistocene terrace deposits that parallel the coast. Water-table gradients along major streams are relatively steep, and gradients along interstream areas are relatively flat. The surficial aquifer recharges the Upper Floridan aquifer where the hydraulic gradient is downward, and it receives water from the Upper Floridan aquifer where the hydraulic gradient is upward.

\section{Upper confining unit}

The surficial aquifer is underlain by the upper confining unit, which primarily consists of the late and middle Miocene Hawthorn Formation. The upper confining unit is made up of all strata between the surficial aquifer and the Upper Floridan aquifer. The unit includes low-permeability clay, and over most of the study area, moderately permeable sand that yields up to $180 \mathrm{gal} / \mathrm{min}$ (Clarke and others, 1990). In some areas, lowpermeability post-Miocene strata are included in the upper confining unit. Generally, the upper confining unit consists of interbedded, locally highly phosphatic beds of sand, silt, clay, and sandy clay. The upper confining unit generally is about $400 \mathrm{ft}$ thick in the Brunswick area (Krause and Randolph, 1989, plate 6). Vertical hydraulic conductivity as determined by laboratory analyses of cores, ranges from $5 \times 10^{-5} \mathrm{ft} / \mathrm{d}$ (Wait, 1965) to $1.1 \mathrm{ft} / \mathrm{d}$ (Wait and Gregg, 1973, table 9). 


\section{Upper Floridan aquifer}

The Upper Floridan aquifer primarily consists of the late Eocene Ocala Limestone and its equivalents (plate 1). The upper part of the Ocala is fossiliferous and it has high effective porosity and permeability. Secondary permeability has developed from the dissolution of the limestone by ground water migrating along bedding planes, joints, fractures, and other zones of weakness, which has increased the permeability of the Ocala.

Throughout the study area, the Upper Floridan aquifer generally consists of one vertically continuous unit; however, in the Brunswick area, the aquifer consists of two permeable freshwater zones--the "upper" and the "lower water-bearing zones," (Wait and Gregg, 1973, p. 16; Gregg and Zimmerman, 1974, p. D17). The upper water-bearing zone is in the uppermost part of the Ocala (plate 1). The fossiliferous, permeable limestone in this zone contributes about 70 percent of the water to wells that tap both zones (Wait and Gregg, 1973). The lower water-bearing zone consists of the basal part of the Ocala and the uppermost part of the middle Eocene strata (plate 1). The recrystallized dolomitic limestone of the lower water-bearing zone generally is less permeable than the limestone of the upper water-bearing zone; in Brunswick, however, the lower water-bearing zone is characterized by caverns that yield large quantities of water (Wait, 1965). Because of their limited areal extent and because there is some hydraulic connection between them, the two zones are treated as a single unit (the Upper Floridan aquifer) for this study.

Transmissivity of the Upper Floridan aquifer in the study area ranges from less than $25,000 \mathrm{ft}^{2} / \mathrm{d}$ to more than $250,000 \mathrm{ft}^{2} / \mathrm{d}$. These values are based on field estimates derived from multi-well and single-well aquifer tests, and from specific capacity data (Krause and Randolph, 1989). Most of the higher transmissivity values were derived from tests of industrial wells for which pumping rates were estimated. The magnitude of these values has recently come under question due to the reevaluation of industrial water use during that period. It is believed that early estimates of industrial pumpage were too high and therefore the resulting transmissivities were overestimated. Results of more recent, controlled aquifer tests have been consistently lower. Unfortunately, all the controlled aquifer tests were limited to the upper water-bearing zone and can only be used as a guide for determining the properties of the entire thickness of the Upper Floridan aquifer. See Maslia and Prowell (1990) for a discussion of these theories and results of the more recent tests.

\section{Middle semiconfining unit and Lower Floridan aquifer}

The Upper Floridan aquifer is underlain by the middle semiconfining unit, which is dense, low-permeability, recrystallized limestone and dolomite of the upper part of the middle Eocene Avon Park Formation (plate 1). The middle semiconfining unit is sufficiently low in permeability to restrict vertical flow, thereby resulting in a head gradient between the Upper and Lower Floridan aquifers. Locally, the unit is breached by faults or fractures that facilitate leakage between the Lower and Upper Floridan. Figure 2 illustrates the structural features identified within the city of Brunswick. See Maslia and Prowell (1990) for a detailed discussion of these features.

The vertical hydraulic conductivity of the middle semiconfining unit is known only from laboratory analyses of five core samples obtained from two water wells in Brunswick. The vertical hydraulic conductivity of the dolomitic limestone, which comprises the middle semiconfining unit, ranges from $4.0 \times 10^{-6}$ to $5.4 \times 10^{-5} \mathrm{ft} / \mathrm{d}$. Leakance of the unit was estimated to be about $1 \times 10^{-7} \mathrm{ft} / \mathrm{d} / \mathrm{ft}$ which is based on a thickness of $100 \mathrm{ft}$ and an average vertical hydraulic conductivity of $1 \times 10^{-5} \mathrm{ft} / \mathrm{d}$. The nearly vertical fractures and faults present in the Brunswick area may increase markedly the vertical hydraulic conductivity and leakance of the unit (Maslia and Prowell, 1990). 


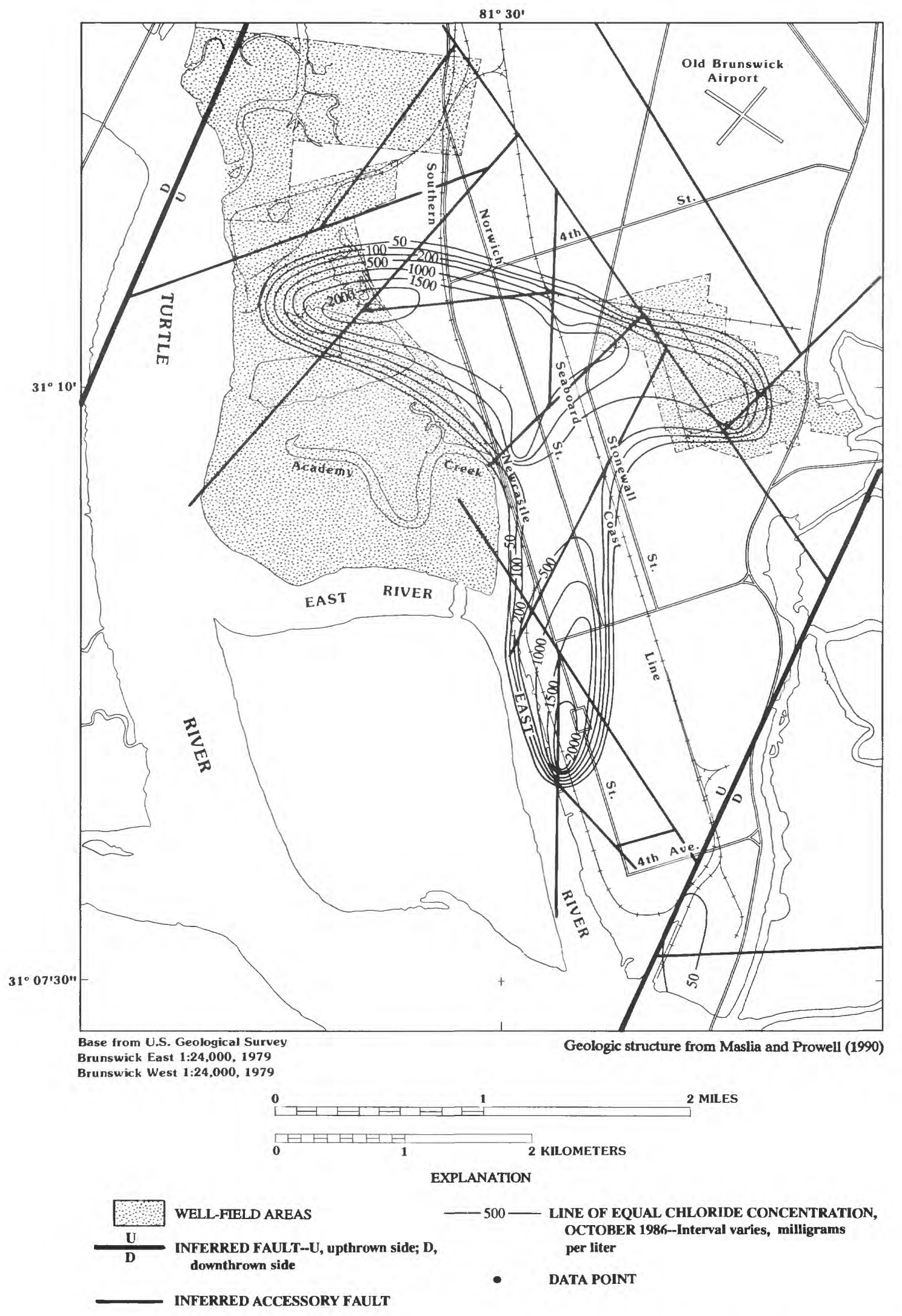

Figure 2.--Inferred faults and chloride concentrations in the Upper Floridan aquifer, Brunswick, Georgia area. 
The Lower Floridan aquifer chiefly consists of middle to lower Eocene carbonate rocks, which are less fossiliferous and more dolomitic than the carbonates that comprise the Upper Floridan. Permeability is secondary and was developed by the dissolution of carbonates by ground water migrating along bedding planes and other zones of weakness. In the Glynn County area, the upper part of the Lower Floridan aquifer consists of interbedded limestone and dolomite in the lower two-thirds of the Avon Park Formation, and the upper part of the Oldsmar Formation. In this area, the Lower Floridan includes the "brackish-water zone" and the "deep freshwater zone" described by Gregg and Zimmerman (1974, plate 1). Neither of these zones is tapped by supply wells in the Glynn County area, but water from both zones leaks upward into the Upper Floridan aquifer through faults or fractures in the middle semiconfining unit. Since development began, saltwater intrusion has occurred throughout the vertical sequence of the Floridan aquifer system within the city of Brunswick. The area of saltwater intrusion for the Upper Floridan aquifer, and the related structural features identified and described by Maslia and Prowell (1990), are shown in figure 2.

Transmissivity data for the Lower Floridan aquifer are nearly nonexistent. Estimates of transmissivity for the Lower Floridan aquifer are based primarily on the calibrated digital model of Krause and Randolph (1989), which in turn is based on thickness and qualitative estimates of permeability made from geophysical well logs. Estimates of transmissivity of the Lower Floridan aquifer range from about 2,000 to nearly $400,000 \mathrm{ft}^{2} / \mathrm{d}$ in the study area.

In Glynn, Camden, and southwestern McIntosh Counties, Ga., and in adjacent Nassau County, Fla., the Lower Floridan aquifer includes a highly permeable cavernous water-bearing zone at its base that has been designated the "Fernandina permeable zone" (Krause and Randolph, 1989). Few wells tap this zone, thus little is known about its extent, thickness, and hydraulic characteristics. Borehole geophysical data give some indication of the relative transmissivity of the zone. Sonic televiewer images and borehole caliper logs of a test well 4 mi southwest of Brunswick show cavities in the Fernandina permeable zone that are tens of feet in height, and that are of undetermined lateral extent. Separating the Fernandina permeable zone from the rest of the Lower Floridan aquifer is a lower semiconfining unit, which consists of low-permeability limestone and dolomite of the Oldsmar Formation (plate 1). The lower semiconfining unit locally is breached by faults or fractures (Maslia and Prowell, 1990). The approximate extent of the Fernandina permeable zone is illustrated in figure 1.

\section{Predevelopment Ground-Water Flow System}

Prior to development, flow in the Floridan aquifer system was controlled chiefly by the distribution of recharge to and discharge from the system, and the hydraulic properties of the hydrologic units. An idealized section of the flow system under predevelopment conditions is shown in figure 3. Prior to development, the flow system was considered to have been at dynamic equilibrium, and the potentiometric surfaces remained nearly unchanged from year to year. Recharge was balanced by natural discharge, resulting in no change in storage in the aquifer system on a long-term average basis. Only seasonal and short-term climatic fluctuations affected the altitude of the potentiometric surfaces. 
Prior to development, the flow system was sluggish and was characterized by flat gradients, low velocities, and low discharge rates. Discharge over most of the study area was attributed chiefly to diffuse upward leakage, except in areas where leakage occurred along solution-enlarged vertical conduits at fractures or faults. In most of the study area, water levels increased with depth throughout the entire vertical section of the flow system, including the surficial aquifer, thus leakage was upward prior to development. It is doubtful that the highly transmissive, cavernous nature of the aquifer system developed under these conditions; more likely it developed as a result of either Pleistocene sea-level fluctuations or karstification during exposure of the carbonates shortly after deposition. (See Miller, 1986, for a complete discussion of cavernous permeability development.)

The source of water to the flow system in the study area prior to development was lateral inflow across the northern and western boundaries and vertical inflow from the surficial aquifer in the northern and western part of the study area. Lateral outflow from the system occurred across the eastern and southern boundaries. Vertical leakage between the Upper Floridan and the surficial aquifer was upward over most of the area. Based on the Glynn County model results, net discharge from the Upper Floridan was about $24 \mathrm{Mgal} / \mathrm{d}$ and total flow through the system was about $74 \mathrm{Mgal} / \mathrm{d}$. The lateral inflow into the study area was about $66 \mathrm{Mgal} / \mathrm{d}$ and the lateral outflow was about $48 \mathrm{Mgal} / \mathrm{d}$. The Fernandina permeable zone in the lower part of the Lower Floridan aquifer was estimated to contribute about $6 \mathrm{Mgal} / \mathrm{d}$ to the flow system prior to development of the aquifer. This probably did not substantially move the freshwater-saltwater interface within the zone. The simulated water budget for predevelopment conditions is given in table 1 . Plate 2 illustrates the potentiometric surface of the Upper Floridan aquifer prior to development.

Table 1. -- Simulated water budget, in million gallons per day, for predevelopment (1880) and present-day (May 1980 and May 1985) flow systems

[Note: Negative numbers denote opposite flow direction. Values are rounded off only enough to maintain the numerical balance of the water budget; implication of accuracy to the degree shown is not intended.]

\begin{tabular}{|c|c|c|c|c|c|c|c|c|c|c|}
\hline \multirow{3}{*}{ Period } & \multicolumn{2}{|c|}{ TOTAL FLOW } & \multicolumn{3}{|c|}{ NET VERTICAL LEAKAGE } & \multicolumn{5}{|c|}{ LATERAL BOUNDARY FLOW } \\
\hline & \multirow[t]{2}{*}{ IN } & \multirow[t]{2}{*}{ OUT } & \multirow{2}{*}{$\begin{array}{l}\text { Surficial } \\
\text { to Upper } \\
\text { Floridan }\end{array}$} & \multirow{2}{*}{$\begin{array}{l}\text { Lower to } \\
\text { Upper } \\
\text { Floridan }\end{array}$} & \multirow{2}{*}{$\begin{array}{c}\text { Fernandina } \\
\text { to Lower } \\
\text { Floridan }\end{array}$} & \multicolumn{2}{|c|}{$\begin{array}{c}\text { Upper } \\
\text { Floridan }\end{array}$} & \multicolumn{2}{|c|}{$\begin{array}{l}\text { Lower } \\
\text { Floridan }\end{array}$} & \multirow[t]{2}{*}{ Pumpage } \\
\hline & & & & & & IN & OUT & IN & OUT & \\
\hline Predevelopment & 74 & 74 & -24 & 2 & 6 & 56 & 35 & 10 & 13 & 0 \\
\hline May 1980 & 324 & 324 & 2 & 137 & 117 & 169 & 27 & 31 & 12 & 280 \\
\hline May 1985 & 307 & 307 & 2 & 133 & 117 & 155 & 29 & 28 & 13 & 260 \\
\hline
\end{tabular}




\section{Present-Day Ground-Water Flow System}

Withdrawal from the aquifer system between 1880 and 1985 has resulted in changes in water levels, rates and distribution of recharge and discharge, direction of ground-water flow, and the intrusion of saltwater. Development of the aquifer system (ground-water withdrawal) has lowered water levels, induced additional recharge, captured natural discharge, increased total flow through the system and, to a lesser extent, reduced aquifer storage and locally caused saltwater intrusion. Figure 4 illustrates an idealized section of the flow system under present-day conditions.

\section{Ground-water withdrawal}

The total estimated withdrawal of ground water in the study area for 1980 was $280 \mathrm{Mgal} / \mathrm{d}$, of which about $57 \mathrm{Mgal} / \mathrm{d}$ was withdrawn at Fernandina Beach, Fla., $36 \mathrm{Mgal} / \mathrm{d}$ at St Marys, $75 \mathrm{Mgal} / \mathrm{d}$ in the Jesup area, and $97 \mathrm{Mgal} / \mathrm{d}$ within Glynn County. The remainder of the pumpage was scattered throughout the study area. The estimated withdrawal for 1985 was about $260 \mathrm{Mgal} / \mathrm{d}$, including about $60 \mathrm{Mgal} / \mathrm{d}$ at Fernandina Beach, Fla., $33 \mathrm{Mgal} / \mathrm{d}$ at St Marys, $74 \mathrm{Mgal} / \mathrm{d}$ in the Jesup area, and $78 \mathrm{Mgal} / \mathrm{d}$ within Glynn County. All withdrawal was from the Upper Floridan aquifer.

\section{Potentiometric surface and water-level decline}

The most obvious impact of ground-water withdrawal on the flow system has been the lowering of water levels. Large withdrawal of ground water, primarily along the coast, has produced large cones of depression in the potentiometric surface that, in places, have coalesced. Several large cones of depression in the potentiometric surface of the Upper Floridan aquifer for May 1980 (Johnston and others, 1981) are shown in plate 2.

The configuration of the potentiometric surface of the Lower Floridan probably is about the same as that of the Upper Floridan, however, sufficient data are not available to construct a potentiometric surface map for the Lower Floridan. Limited water-level data from both aquifers in the study area indicate that the water levels in the Lower Floridan are only slightly higher than those in the Upper Floridan. Fairchild and Bentley (1977, p.13) reported water levels in the Lower Floridan that were as much as $20 \mathrm{ft}$ higher than those in the Upper Floridan at Fernandina Beach, Fla. This probably represents a maximum; generally, water-level differences are less than $5 \mathrm{ft}$. Maximum differences in water levels between the Upper and the Lower Floridan probably occur in areas where the cones of depression are deeper and in areas where confinement is greatest and hence upward leakage is small.

The deeper cones of depression of the potentiometric surfaces are in the areas of large ground-water withdrawal, such as at St Marys, Ga.-Fernandina Beach, Fla., in the southern part of the study area. Although ground-water withdrawal also is large at Brunswick, the cone of depression that has developed there is smaller. Ground-water withdrawal in 1980 at St. Marys-Fernandina Beach and Brunswick were about equal. However, the cone of depression produced at Brunswick is notably shallower as a result of geologic and structural characteristics that are allowing significant quantities of water to leak upward. The reader is referred to Maslia and Prowell (1990) for a discussion of the hydrogeologic anomalies of this area.

$$
\text { page } 12 \text { is colored plute }
$$


Total flow through the system under present-day conditions (May 1985) in the Glynn County area is larger than that for predevelopment conditions because of withdrawal within and outside the study area. Simulation results from the regional model (discussed later in this report) indicate that lateral flow into the study area was about 183 $\mathrm{Mgal} / \mathrm{d}$ and lateral flow out of the system was about $42 \mathrm{Mgal} / \mathrm{d}$. The simulated water budget for May 1980 and May 1985 flow conditions is given in table 1. The upward gradient between the Upper Floridan aquifer and the water table was reversed in areas of large withdrawal, and the vertical flow upward from the Fernandina permeable zone increased from $6 \mathrm{Mgal} / \mathrm{d}$ to about $117 \mathrm{Mgal} / \mathrm{d}$ between predevelopment and May 1985 .

Under present-day conditions (May 1985), the flow system was determined to be in an approximate steady state rather than a transient one. This was based on the observation that at least on a regional basis, no long-term water-level decline is occurring; and thus, no substantial contribution of water to the flow system presently is derived from storage in the aquifer. Locally in the coastal area, small water-level declines of less than about $1 \mathrm{ft}$ per year are occurring but the amount of water released from storage (if any) as a result of these declines probably is small in comparison with the total ground-water withdrawal for the area. That quantity was determined by using the equation

$$
\mathrm{Q}=\mathrm{Sh} / \mathrm{t} \mathrm{A} \text {, }
$$

where

$\mathrm{Q}$ is the rate of water released from aquifer storage $\left(\mathrm{ft}^{3} / \mathrm{s}\right)$,

$\mathrm{S}$ is the storage coefficient (dimensionless),

$\mathrm{h} / \mathrm{t}$ is the average areal water-level decline $(\mathrm{ft} / \mathrm{s})$, and

$A$ is the area of water-level decline $\left(\mathrm{ft}^{2}\right)$.

By using an average storage coefficient of 0.0003 , a water-level decline of $35 \mathrm{ft}$ over the period of record of 42 years for well $34 \mathrm{H} 328$ (fig. 5), and the total model area of $6,080 \mathrm{mi}^{2}$, the rate of water released from storage (if any) was calculated to be $1.34 \mathrm{ft}^{3} / \mathrm{s}$ or 0.87 $\mathrm{Mgal} / \mathrm{d}$, which was approximately 0.3 percent of the total pumpage $(260 \mathrm{Mgal} / \mathrm{d})$ in the model area.

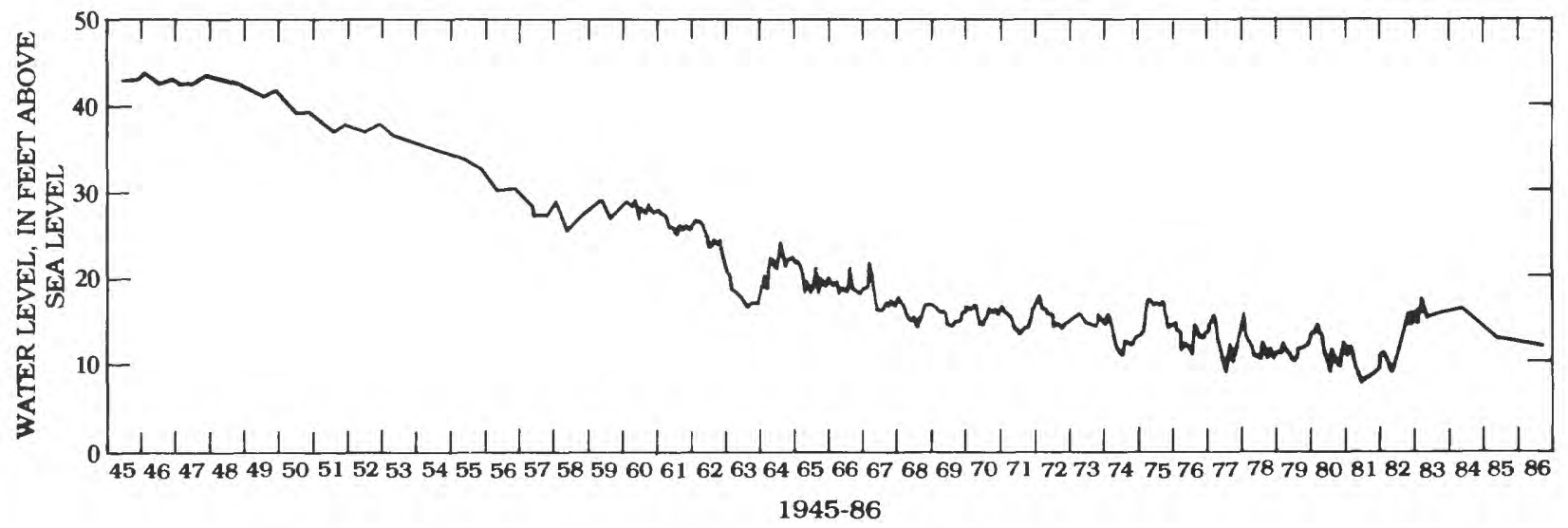

Figure 5.--Water-level fluctuation in well $34 \mathrm{H} 328$ completed in the Upper Floridan aquifer, Brunswick, Georgia, 1945-1986. 


\section{DIGITAL MODEL OF THE AQUIFER SYSTEM}

The digital model is a mathematical representation of the characteristics of an aquifer system and the flow of water through that system. The physical characteristics first are incorporated into a conceptual model by using all available information. The relation of these characteristics to ground-water flow then are described numerically by using the differential equations of flow through porous media. The mathematical description is based on a simplified conceptual model, owing to the complexities of the physical system.

\section{Mathematical Description and Model Assumptions}

The digital simulation code used in this study computed the potentiometric head in a confined/unconfined aquifer system, at any time, as a function of distributed aquifer and confining-bed characteristics in conjunction with distributed values of ground-water withdrawal. These water levels were obtained by solving the equation for flow through porous media. Although analytical techniques exist, a digital model was required to treat the scale and complexity of the Floridan aquifer system.

The aquifer system was modeled by using a three-dimensional, finite-difference computer code. The model was used to solve a set of finite-difference equations by using a strongly implicit procedure (SIP) originally described by Stone (1968) for problems in two dimensions, and extended by Weinstein and others (1969) to problems in three dimensions. The three-dimensional scope of the code actually was that of two-dimensional, horizontal flow, coupled with one-dimensional, vertical flow, which was used to represent leakage through confining units. The assumptions inherent for this type of quasi-three-dimensional flow field were that flow within the aquifer was horizontal and that non-horizontal flow components were negligible; and that flow within the confining units was vertical only, and that non-vertical flow was negligible.

Assumptions made by the authors of the model code (McDonald and Harbaugh, 1984) for calculations of the water level at a grid block, in which pumping occurs were that (1) flow is within a rectangular grid block that could be described by a steady-state equation having no source term except for the well discharge or recharge, (2) the aquifer is isotropic and homogeneous within each block, (3) only one well is assigned to each block, and that well fully penetrates the aquifer, (4) flow is horizontal and laminar, and (5) well loss is negligible. The water level at a pumping grid block does not represent the water level at the well, but rather is an average water level for the entire grid block.

The assumption that the flow system during May 1980 and May 1985 was under steady-state conditions required that the contribution of water from aquifer storage to the aquifer yield (pumping) be negligible. During steady-state, the flow out of the model area due to pumping and boundary discharge was equalized by the lateral and vertical flow into the model area. 


\section{Model Design}

Simulation of the ground-water flow system in the study area was accomplished by using the U.S. Geological Survey's modular model developed by McDonald and Harbaugh (1984). For modeling purposes, it was necessary to numerically describe boundary conditions, aquifer system layers, and flow characteristics of the system relative to a discretized set of locations within the area of interest. A description of the boundary conditions, finite-difference grid, and aquifer-system layers follows.

\section{Finite-difference grid}

The Glynn County model area was areally discretized into 94 columns and 110 rows by using a finite-difference grid having variable spacing. The variable grid is used to achieve high resolution and fine detail in areas of interest such as pumping centers and less detail in areas of less importance. The smallest grid blocks are located in the center of the model and correspond to the area of greatest pumping and water-level variation. This area consists of 512 square blocks, each $1,320 \mathrm{ft}$ on a side, and covering an area of $32 \mathrm{mi}^{2}$. The block sizes increase outward from the center of the grid. At the four corners of the model, the square grid blocks cover an area of $16 \mathrm{mi}^{2}$.

The finite-difference grid for this study was based on the design of the uniform model grid for the three-dimensional Floridan RASA model of Krause and Randolph (1989). The Glynn County model grid is oriented with the RASA grid, and the grid blocks of the new grid are divisions of the original RASA $16-\mathrm{mi}^{2}$ grid blocks. The four corners of the Glynn County model coincide exactly with four grid blocks of the RASA model ( $4 \mathrm{mi}$ on a side). Each of the smallest blocks in the center of the Glynn County model (1/4th mi on a side) are 1/256th the area of the corresponding RASA model grid block. The direct correlation between the two models allowed for efficient transfer of aquifersystem and flow characteristics. The boundaries of the RASA model grid and the Glynn County model grid are shown on figure 1. Hydrologic data input to the model are defined at all active grid blocks and represent an average value of a given parameter over the area covered by the grid block.

\section{Model layers}

The conceptualized Floridan aquifer system (figs. 3, 4) consists of two aquifers (Upper and Lower Floridan), which are simulated as active layers using the mathematical equations of the digital model. The aquifer system is overlain by the surficial aquifer and underlain by the Fernandina permeable zone, each of which is simulated as a specifiedhead, source-sink layer. Lateral flow in the surficial aquifer and the Fernandina permeable zone is not simulated. In areas where the aquifer system is not underlain by the Fernandina permeable zone, the Lower Floridan aquifer is simulated as being confined from below by an impermeable (no-flow) layer.

Although the model code allows for representation of the confining units in the same manner as the aquifers, this model simulates the units as membranes having no vertical dimension and conducting water vertically but not horizontally. In addition to the assumption that horizontal flow in the confining units could be neglected, it was assumed that water released from storage in the confining units also could be neglected. Both of these assumptions were considered valid with respect to the confining units simulated. 


\section{Lateral boundary conditions}

Ideally, model boundaries are chosen to coincide with hydrologic boundaries that do not shift during the time or conditions of the model analysis. In the case of the Glynn County model, natural boundaries of the Floridan aquifer system extend far beyond the study area, which made it impractical to configure the boundaries of the model with natural boundaries of the aquifer. Because the study area is included in the larger RASA model, flow at the boundary of the Glynn County model can be determined by using simulated nodal flows internal to the RASA model that are coincident with the Glynn County model boundaries. Boundary flows are determined by applying Darcy's equation of flow, which is

$$
\mathrm{Q}=\mathrm{KA}\left(\mathrm{h}_{2}-\mathrm{h}_{1}\right) / \mathrm{L}
$$

where

$\mathrm{Q}$ is the flow across the face of the boundary $\left(\mathrm{ft}^{3} / \mathrm{s}\right)$,

$\mathrm{h}_{2}$ is the water level at a point $2 \mathrm{mi}$ outside the boundary ( $\mathrm{ft}$ ),

$h_{1}$ is the water level at a point 2 mi inside the boundary ( $\mathrm{ft}$ ),

$\mathrm{K}$ is the average hydraulic conductivity of the aquifer at points $2 \mathrm{mi}$ inside and outside the boundary $(\mathrm{ft} / \mathrm{s})$,

$\mathrm{A}$ is the cross-sectional area perpendicular to the (lateral) flow $\left(\mathrm{ft}^{2}\right)$, and

$L$ is the length of the flow path between $h_{2}$ and $h_{1}$ (4 mi or $21,120 \mathrm{ft}$ ).

The resulting boundary flow, calculated by the RASA model at each boundary grid block of the model, was divided and distributed as input to the adjacent grid blocks of the Glynn County model, based on divisions of that block in the Glynn County model. The number of divisions of a RASA 4-mi-block side in the Glynn County model ranged from 1 to 16 . Flow values then were input to the Glynn County model as recharge or discharge wells at boundary nodes to represent lateral flow into or out of the model area, respectively. New boundary flows could be calculated by the RASA model for any flow regime, which allowed for more accurate predictive simulations without adverse boundary influences.

\section{Hydrologic input data}

Data input to the model involves discretizing available hydrogeologic data so that each block in the finite-difference grid is assigned a value. For steady-state simulations, data input required for the Glynn County model are nodal values of water level of the surficial aquifer and the Fernandina permeable zone, transmissivities of the Upper and Lower Floridan aquifers, and confining-unit leakances for the upper confining unit, middle semi-confining unit and lower confining unit. Although not required for computation in the digital model, values of water level for the Upper and Lower Floridan aquifers were input to the model for calibration purposes -- determining residual error and making waterlevel decline maps. Sources of the data used in the simulation of the four-layer model are discussed in the following sections. 
Nodal values for the estimated predevelopment (1880) potentiometric surface of the Upper Floridan aquifer (plate 2) were derived from a map covering the entire Floridan aquifer system by Johnston and others (1980). The 1880 potentiometric surface is an estimate of the general configuration of the potentiometric surface of the Upper Floridan aquifer as it existed prior to development. Data input for Upper Floridan water-level values were interpolated directly from the equipotential contours of the estimated potentiometric surface. The resulting water-level matrix and the estimated water-level differences between the Upper and Lower Floridan aquifers provided data input for Lower Floridan water-level values.

The potentiometric surfaces of May 1980 and May 1985 were used to simulate the present-day flow system. These data are considered to be more reliable than those of the predevelopment surface owing to an increased number of control points, a better-defined vertical datum, and an improved understanding of the flow system. These surfaces were discretized in the same manner as the predevelopment surface; a map by Johnston and others (1981) was used for May 1980 and a map by Clarke (1987) was used for May 1985. Assumptions about the relation between the Upper and Lower Floridan aquifers under stressed conditions were made based on generalized information about vertical gradients within the flow system and from measured water-level data. This relation was used to derive a Lower Floridan potentiometric surface for use in the model. See Krause and Randolph (1989) for a discussion of the Lower Floridan.

The water level in the surficial aquifer fluctuates due to climatic influences and seasonal variations. For purposes of simulation, however, the average altitude of the surficial aquifer is considered to be constant with time, and therefore, can be simulated as a specified-head boundary layer. This boundary condition allows the surficial aquifer to act as a hydraulic source or sink to the underlying Upper Floridan aquifer, depending on the vertical hydraulic gradient between the two aquifers. Leakage that occurs between the Upper Floridan and the surficial aquifers then can be simulated without having to simulate the response of the surficial aquifer itself. The water level in the surficial aquifer was estimated from land- and water-surface altitudes taken from topographic contour maps. In topographic high areas and in areas where deposits of permeable material were thick, the water level was estimated to be about 15 to $20 \mathrm{ft}$ below land surface. In areas along the coast, the water level was estimated to be 5 to $10 \mathrm{ft}$ below land surface, and in salt marsh and estuarine areas, the water level was estimated at sea level.

In offshore areas, the water level in the top of the surficial aquifer was related to the depth of seawater. Because saltwater is $1 / 40$ more dense than freshwater (density of seawater is 1.025 grams per cubic centimeter), a column of freshwater equal in weight to the offshore column of saltwater would extend above sea level $1 / 40$, the depth of the sea (length of the saltwater column) at that point. Thus, the freshwater head equivalent to sea level was $1 / 40$ the depth of the sea. This equivalent freshwater head was used for the surficial aquifer in offshore areas. The model could not address variable flow caused by differences in water density.

The Fernandina permeable zone also is simulated as a specified-head, source-sink layer owing to the negligible water-level response in that zone to pumping from the rest of the Floridan aquifer system. Although few data were available, May 1980 and May 1985 water levels in the Fernandina permeable zone were estimated to be slightly higher than that in the rest of the Lower Floridan aquifer under predevelopment conditions. This relation and a few water-level measurements were used to estimate water levels for the digital model. See Krause and Randolph (1989) for a more complete discussion of the Fernandina permeable zone throughout its area of occurrence. 


\section{Transmissivity}

Values for the distribution of transmissivity in the Upper Floridan aquifer were derived from field-measured values of hydraulic conductivity, aquifer thickness, specific capacity, and transmissivity. The discretized values of transmissivity ranged from about 8,600 to $475,000 \mathrm{ft}^{2} / \mathrm{d}$ (plate 3). Because of the lack of data for the Lower Floridan aquifer, the distribution of transmissivity values in this layer of the model is based on a qualitative understanding of the hydrogeology of the aquifer utilizing thickness data and geophysical logs and on the results of the RASA model simulations (Krause and Randolph, 1989).

Transmissivity of the surficial aquifer and the Fernandina permeable zone were not used in the model because of their designation as source-sink, constant-head layers. The model did not simulate flow in these layers.

Distributed values of transmissivity were obtained by transferring RASA model transmissivity values directly into the Glynn County model. However, because discretization of the Glynn County model grid was much finer than that of the RASA model, more variation of transmissivity was possible where information about it was available. Water-level changes resulting from large scale increases and decreases in industrial pumping in the city of Brunswick were evaluated and transmissivity values were derived for the upper water-bearing zone by Maslia (1987). Transmissivity data for the entire section of the Upper Floridan aquifer within Glynn County were documented by Wait and Gregg (1973). However, results of many of these analyses now are considered to be larger than the actual transmissivity of the Upper Floridan in that area (Maslia and Prowell, 1990). They are included on plate 3 mainly because of the lack of data for the entire thickness of the Upper Floridan in Glynn County and should be considered as an upper range of expected transmissivity for the area. The calibrated distribution of transmissivity in the Upper Floridan aquifer, presented in plate 3, represents the values derived from the RASA model along with some variations based on qualitative information about the flow system obtained since the calibration of the RASA model, including the reinterpretation of historical data and the more recent aquifer tests of the upper waterbearing zone by Maslia and Prowell (1990).

\section{Leakance}

Values of leakance, defined as the ratio of the vertical hydraulic conductivity of the confining unit to the confining unit thickness, were derived from available field data of hydraulic conductivity and thickness (Wait, 1965; Wait and Gregg, 1973). Leakance values used in the model had to represent any anomaly that could affect the water level at a given grid block at the scale simulated. For example, solution-enlarged joints and/or faults through the middle and lower semiconfining units in the Brunswick area were represented by using high leakance values based on the theory that these features enhance the vertical flow of water through the confining units (Krause and Randolph, 1989; Maslia and Prowell, 1990). Initially, distributed leakance values for the Glynn County model were derived from the RASA model. These values were adjusted, however, through calibration and on the basis of additional information gathered about the geology, hydrology, and water quality in the study area (Clarke and others, 1990; Maslia and Prowell, 1990). 


\section{Well discharge}

As part of the reconnaissance phase of the Brunswick, Georgia, Area Water Resources Management Study, the Coastal Area Planning and Development Commission (CAPDC) conducted a ground-water-use survey of public and private water suppliers in Camden, Glynn, and McIntosh Counties for 1980 (Coastal Area Planning and Development Commission, written commun., 1982). Water use in 1980 for other Georgia counties within the model area were derived from Pierce and others (1982). Water-use data for Nassau County, Fla., were obtained from unpublished records (E.C. Hayes and D.P. Brown, U.S. Geological Survey, written commun., May 1981 and May 1983).

Water-use data for 1985 were less detailed and less comprehensive than those for 1980. Most of the 1985 water-use information for the Georgia counties was obtained from the files of the Georgia Department of Natural Resources, Environmental Protection Division and the U.S. Geological Survey. Water-use data for Florida were obtained from Marella (1986) and unpublished records (E.C. Hayes and D.P. Brown, U.S. Geological Survey, written commun., April 1986).

For simulating well discharge, the total ground-water use over the entire grid block was modeled as one well discharging at the center of the block. The distribution of pumping simulated by the model is presented for May 1980 and May 1985 conditions on plate 3 .

\section{Model Calibration}

The purpose of the digital model is to (1) quantify the conceptual model; (2) better define the ground-water flow system; and (3) predict future ground-water flow conditions in the Glynn County area. To achieve the above, the initial digital representation of hydrologic field data must be adjusted through a model calibration process. During the calibration process, the goal is to obtain the best possible match between values of water level in the Upper and Lower Floridan aquifers and those simulated by the models, by adjusting the various input parameter values. Simulated water budgets also must reasonably approximate independent evaluations of ground-water flow, where such estimates are available.

Model calibration was based on the simulation of the predevelopment condition and a stressed condition for the flow system. The stressed period chosen was 1980 because of the detailed data available for that period. The May 1980 potentiometric surface mapping effort was one of the most intensive, simultaneous data-collection efforts related to waterlevel measurements in the Floridan aquifer system, and the 1980 water-use survey performed by the CAPDC was the most comprehensive water-use data collection efforts conducted for the Floridan aquifer system in the coastal area of Georgia. The 1985 conditions of the flow system were used as a somewhat independent verification of the model calibration and resulted in some further adjustment to the input parameters of the model. 
Model calibration was achieved through matching the measured and the simulated potentiometric surfaces of the Upper Floridan aquifer for predevelopment (1880) and stressed (May 1980) conditions through an iterative process of parameter adjustment; thus, inaccuracies in those surfaces would have affected the validity of the calibration. The predevelopment potentiometric surface probably was accurate to within about $20 \mathrm{ft}$ in the offshore areas and 10 to $15 \mathrm{ft}$ elsewhere. (See Johnston and others (1980) for a discussion of the predevelopment potentiometric surface.) This potentiometric surface accuracy was the criterion used to measure acceptable calibration accuracy. The May 1980 potentiometric surface was more accurate than the predevelopment surface (probably within $10 \mathrm{ft}$ except offshore and in the areas of large withdrawal where an acceptance criterion of $20 \mathrm{ft}$ was used), and therefore, the model was more reliable when calibrated against that surface. Criteria for model calibration were based on the probable inaccuracies; calibration was achieved when the differences between simulated and observed water levels were less than the potential inaccuracies.

\section{Steady-state calibration of the predevelopment flow system}

The calibration procedure was begun by using the calibrated parameters and the conceptual model of the RASA predevelopment simulation. The parameters within the study area were discretized for use in the Glynn County model grid. Changes in aquifer parameters were then made in both the RASA and the Glynn County models as necessary to maintain conformance between the two models. Changes also were made to RASA model aquifer parameters outside the Glynn County model area to effect changes in lateral flow across the Glynn County model boundaries. The magnitude of parameter change from the existing RASA model was small. However, considerable variation within a given RASA model grid block was possible due to the increase in resolution achieved through the variable grid and the incorporation of site-specific aquifer-test data.

The calibration procedure progressed by adjusting the aquifer system parameters, which were based on results of previous simulations, as well as new data that may have become available. The adjustment of these parameters was somewhat subjective, and the parameters derived through successful adjustments did not necessarily give a unique solution. Therefore, it was necessary to ensure that the calibrated parameters were within acceptable ranges.

A constant check was made to ensure that the aquifer parameters used in the detailed Glynn County model related to those in the large-scale RASA model. Computer programs were used to convert the Glynn County model data to the RASA model grid. Vertical flows calculated by each of the models also were compared and used as a basis for calibration. A simulated water budget for the predevelopment flow system in the model area is given in table 1. A comparison of the estimated and simulated predevelopment potentiometric surfaces is shown on plate 2. A statistical summary of differences between the measured and simulated water levels for predevelopment, May 1980, and May 1985 conditions is presented in table 2 . The resulting mean error between simulated and estimated water levels was $1.6 \mathrm{ft}$ for the Upper Floridan and $2.4 \mathrm{ft}$ for the entire flow system for predevelopment conditions (tables 2 and 3 ). 


\section{Table 2.--Statistical summary of differences between measured and simulated water levels for the Upper Floridan aquifer}

\begin{tabular}{lccc}
\hline $\begin{array}{l}\text { Calibration } \\
\text { period }\end{array}$ & $\begin{array}{c}\text { Mean } \\
\text { error } \\
\text { (feet) }\end{array}$ & $\begin{array}{c}\text { Standard } \\
\text { deviation } \\
\text { (feet) }\end{array}$ & $\begin{array}{c}\text { Root-mean- } \\
\text { square error } \\
\text { (feet) }\end{array}$ \\
\hline Predevelopment & 1.6 & 0.9 & 1.8 \\
May 1980 & 2.8 & 1.7 & 3.3 \\
May 1985 & 1.9 & 1.6 & 2.5 \\
\hline
\end{tabular}

Table 3.--Statistical summary of differences between measured and simulated water levels for the Floridan aquifer system

\begin{tabular}{lccc}
\hline $\begin{array}{l}\text { Calibration } \\
\text { period }\end{array}$ & $\begin{array}{c}\text { Mean } \\
\text { error } \\
\text { (feet) }\end{array}$ & $\begin{array}{c}\text { Standard } \\
\text { deviation } \\
\text { (feet) }\end{array}$ & $\begin{array}{c}\text { Root-mean- } \\
\text { square error } \\
\text { (feet) }\end{array}$ \\
\hline Predevelopment & 2.4 & 1.2 & 2.7 \\
May 1980 & 3.6 & 3.7 & 5.1 \\
May 1985 & 5.6 & 8.2 & 9.9 \\
\hline
\end{tabular}

Steady-state calibration of the present-day flow system

The 1980 potentiometric surfaces for the Floridan aquifer system in the Glynn County area were used to calibrate the model under stressed conditions. Minor adjustments to the aquifer and confining unit characteristics near the large pumping centers were required during simulation of 1980 conditions to achieve a satisfactory match between the measured and simulated potentiometric surfaces. Some discrepancies exist between the two surfaces owing to the lack of definition of the measured potentiometric surface in the area of St Marys, Ga. and Fernandina Beach, Fla., where multiple cones of depression have combined to create an asymmetric area of water-level decline. Observed and calibrated potentiometric surfaces for May 1980 conditions are shown on plate 2. The flow system for May 1985 pumping conditions was similar to that of May 1980 with only a $20 \mathrm{Mgal} / \mathrm{d}$ decrease in pumping over the 5-year period. Simulated and observed potentiometric surfaces for May 1985 conditions are shown in plate 2. 
Simulated water levels at nodes that represented large withdrawal generally were higher than observed water levels. Although the model was calibrated by using regional transmissivities that corresponded to the entire permeable section of the Upper Floridan aquifer, actual and simulated pumpage generally were for wells that only partially penetrated the aquifer. Another factor that affected the match between simulated and measured water levels was the grid block size. The simulated water level for a given pumping grid block represents the average water level over the area of the grid block. This was compared with water levels that were estimated from potentiometric contours, so areas where a large gradient was present within a grid block were more difficult to match due to the difficulty of estimating an average water level.

Confidence in the calibration of the model was greater for the Upper Floridan aquifer than for the Lower Floridan aquifer. The Lower Floridan aquifer was simulated by using reasonable estimates of the characteristics of the aquifers and confining units, but data on the actual configuration of the potentiometric surface and hydraulic properties were not available. This prohibited a rigorous, quantitative check on the calibration for the Lower Floridan. Model simulations for the Lower Floridan aquifer were judged to be reasonable, however, in that simulated water levels matched observed water levels nearly as well as for the Upper Floridan aquifer. The lesser degree of confidence in the observed Lower Floridan aquifer water levels, upon which the calibration was judged, made calibration of the Lower Floridan aquifer potentially less reliable. It is believed, however, that the entire Floridan aquifer system was calibrated to an acceptable degree.

The models were presumed calibrated when vertical flux between similar model areas matched within 10 percent of each other and the match between the measured and simulated water levels was considered acceptable. The mean error between the simulated and measured or estimated water levels was $2.8 \mathrm{ft}$ for the Upper Floridan aquifer and 3.6 for the entire flow system for May 1980 conditions (tables 2 and 3).

\section{Model Sensitivity to Parameter Changes}

An analysis was made to determine the sensitivity of the calibrated model to changes in input parameters. The evaluated aquifer system characteristics included the transmissivity of the active layers and the leakance of the confining units. Each of the parameters was changed independently by a factor of 0.5 and 2.0 while all other parameters were held constant. On the basis of the resulting differences in water level, the Glynn County model, calibrated to May 1980 conditions, was most sensitive to changes in transmissivity of the Upper Floridan aquifer and the vertical hydraulic conductivity of the lower semiconfining unit (between the Fernandina permeable zone and the Lower Floridan aquifer). Results of the sensitivity analysis indicate that the response of the Floridan aquifer system to pumping in the Glynn County area probably is controlled primarily by water supplied vertically from the Fernandina permeable zone and laterally from upgradient areas of the Upper Floridan aquifer. 
Sensitivity was measured in terms of the absolute mean error, the standard deviation, and the absolute root-mean-square error (RMSE) between observed and simulated water levels for 1980. Mathematically, these parameters are represented by

$$
\mu=\frac{1}{\mathrm{~N}} \sum_{\mathrm{i}=1}^{\mathrm{N}}\left(\mathrm{h}_{\mathrm{S}}-\mathrm{h}_{\mathrm{O}}\right)
$$

where

$\mu$ is the mean water-level residual,

$\mathrm{h}_{\mathrm{S}}$ is the simulated water level,

$\mathrm{h}_{\mathrm{o}}$ is the observed water level, and

$\mathrm{N}$ is the number of measurements or active nodes.

$$
\mathrm{SD}=\left[\frac{1}{\mathrm{~N}-1} \quad \sum_{\mathrm{i}=1}^{\mathrm{N}}\left(\overline{\mathrm{h}}_{\mathrm{S}}-\mu\right)^{2}\right]^{\frac{1}{2}}
$$

where

$\mathrm{SD}$ is the standard deviation, and

$\mathrm{h}_{\mathrm{S}}$ is the simulated water-level residual.

$$
\operatorname{RMSE}=\left[\frac{1}{N} \quad \sum_{\mathrm{i}=1}^{\mathrm{N}}\left(\mathrm{h}_{\mathrm{S}}-\mathrm{h}_{\mathrm{O}}\right)^{2}\right]^{\frac{1}{2}}
$$

where

RMSE is the root-mean-square error.

Results of the sensitivity analysis are given in tables 4 and 5 for the Upper Floridan aquifer and the Floridan (Upper and Lower) aquifer system.

The model also was tested to determine the sensitivity of the simulation to the boundary conditions. A general-head type boundary condition was applied to all sides of the model for both layers using the simulated RASA water levels outside the model boundaries for the constant-head control. Results indicate that the model is relatively insensitive to the change in boundary condition with a slight reduction in error realized with the use of calculated flow rather than general-head boundaries. The total flow through the system changed from about $501 \mathrm{ft}^{3} / \mathrm{s}$ (324 Mgal/d) using the calculated flow, to about $511 \mathrm{ft}^{3} / \mathrm{s}$ (330 Mgal/d) using the general-head boundaries for May 1980 conditions. Statistical summaries of sensitivity analyses for boundary conditions also are included in tables 4 and 5 . 
Table 4.--Statistical results of the sensitivity analysis using the Upper Floridan aquifer water levels as the basis for comparison, May 1980 conditions

$$
\text { [--, not applicable] }
$$

\begin{tabular}{|c|c|c|c|c|}
\hline Parameter & Multiplier & $\begin{array}{l}\text { Mean } \\
\text { error } \\
\text { (feet) }\end{array}$ & $\begin{array}{l}\text { Standard } \\
\text { deviation } \\
\text { (feet) }\end{array}$ & $\begin{array}{l}\text { Root-mean- } \\
\text { square error } \\
\quad(\text { feet })\end{array}$ \\
\hline Transmissivity of the & 2.0 & 8.6 & 6.3 & 10.6 \\
\hline Upper Floridan & 0.5 & 13.1 & 6.7 & 14.7 \\
\hline Transmissivity of the & 2.0 & 2.9 & 2.3 & 3.7 \\
\hline Lower Floridan & .5 & 4.0 & 2.1 & 4.5 \\
\hline Leakance of the lower & 2.0 & 6.3 & 2.1 & 6.6 \\
\hline semiconfining unit & .5 & 9.4 & 4.2 & 10.3 \\
\hline Leakance of the middle & 2.0 & 2.5 & 1.6 & 3.0 \\
\hline semiconfining unit & .5 & 3.5 & 2.1 & 4.1 \\
\hline Leakance of the upper & 2.0 & 2.6 & 1.8 & 3.2 \\
\hline confining unit & .5 & 3.6 & 2.0 & 4.1 \\
\hline General-head boundary & -- & 4.8 & 2.2 & 5.3 \\
\hline
\end{tabular}

Table 5.--Statistical results of the sensitivity analysis using the Floridan aquifer system water levels as the basis for comparison, May 1980 conditions

$$
\text { [--, not applicable] }
$$

$\begin{array}{lccc}\text { Parameter } & \text { Mean } & \text { Standard } \\ \text { deviation } & \text { Root-mean- } & \text { (feet) } & \begin{array}{c}\text { square error } \\ \text { (feet) }\end{array} \\ & \text { (feet) } & \text { (ror } & \end{array}$

Transmissivity of the Upper Floridan

Transmissivity of the Lower Floridan

Leakance of the lower semiconfining unit

Leakance of the middle semiconfining unit

Leakance of the upper confining unit

General-head boundary

$\begin{array}{rr}2.0 & 9.8 \\ 0.5 & 10.7 \\ 2.0 & 4.7 \\ .5 & 3.7 \\ 2.0 & 8.4 \\ .5 & 8.4 \\ 2.0 & 3.2 \\ .5 & 4.3 \\ 2.0 & 3.9 \\ .5 & 3.9 \\ -- & 4.7\end{array}$

$\begin{array}{ll}3.7 & 3.1\end{array}$

$\begin{array}{ll}3.5 & 5.9\end{array}$




\section{EFFECTS OF HYPOTHETICAL CHANGES IN GROUND-WATER WITHDRAWAL}

The calibrated model was used to predict the effects of potential future changes in the distribution and amount of ground-water withdrawal on the flow system of the Upper Floridan aquifer. The future withdrawal scenarios presented here are based on future increases in ground-water demand that might occur in the area.

The steady-state model used for simulating the effects of possible changes in withdrawal produces a potentiometric surface that represents the water level in the aquifer after the system has adjusted to the increased withdrawal. The resulting potentiometric surface represents a new point of equilibrium, and the associated water levels remain stable until the next change in pumping occurs. In a steady-state simulation, time is not a factor, thus a gradual increase to a specified amount and an instantaneous increase to that same amount will result in the same change in water level after equilibrium is reached.

\section{Increased Withdrawal on Colonels Island, Glynn County}

A projected increase in ground-water withdrawal of $10 \mathrm{Mgal} / \mathrm{d}$ on Colonels Island was simulated to assess the effects that future development on the island may have on the water resources of nearby Brunswick. The additional withdrawal was divided evenly between two well fields on the island. The largest water-level declines were 18.7 and $13.4 \mathrm{ft}$ at the two pumping grid blocks. The resultant water-level decline in the area of known saltwater intrusion in Brunswick was 2 to $3 \mathrm{ft}$. Figure 6 shows the simulated water-level change caused by the increased withdrawal. 


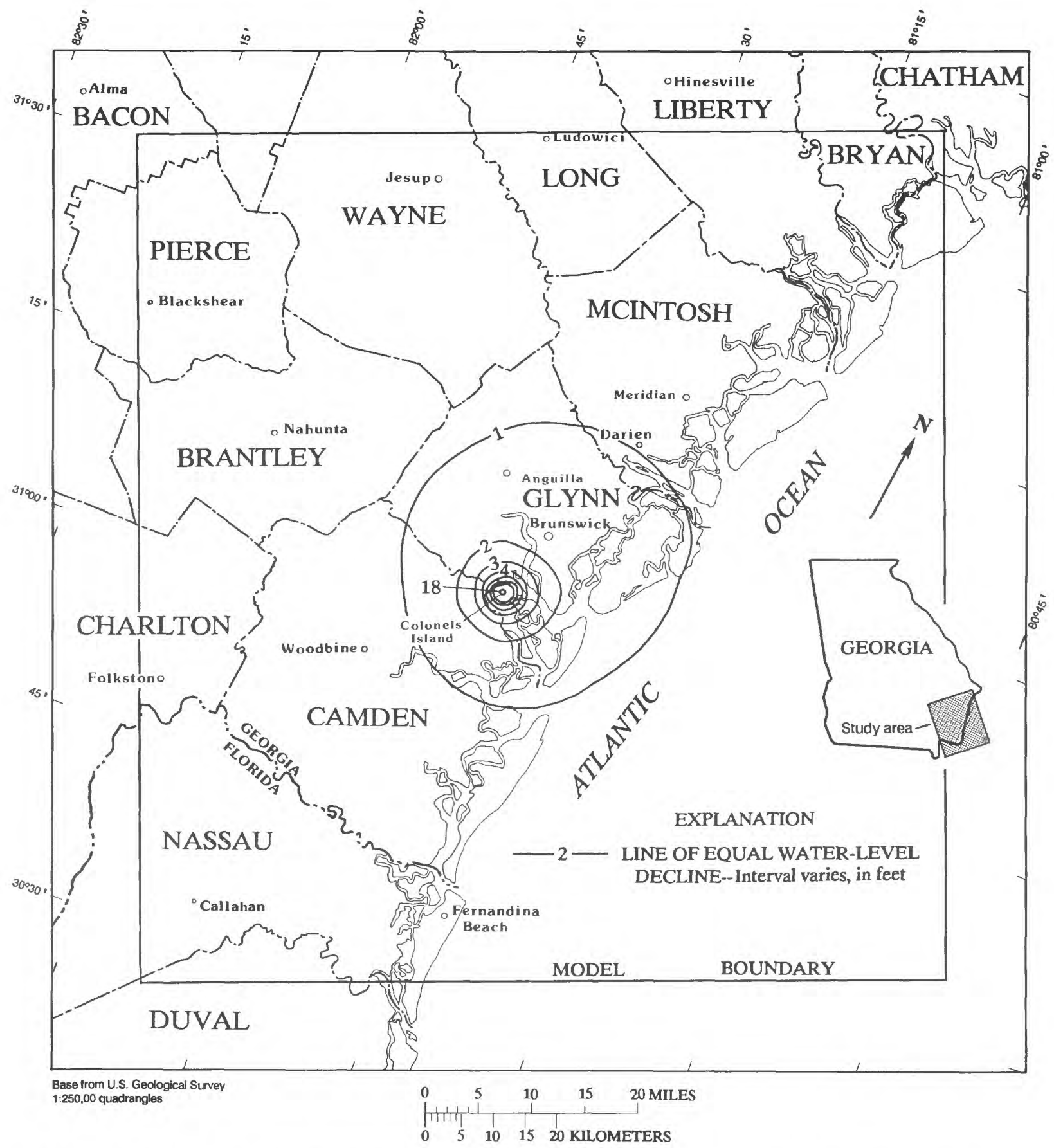

Figure 6.--Simulated water-level decline caused by an increase in withdrawal of 10 million gallons per day on Colonels Island, Glynn County. 


\section{Decreased Withdrawal in Brunswick \\ and Increased Withdrawal near \\ Anguilla, Glynn County}

A projected decrease in withdrawal of about $3 \mathrm{Mgal} / \mathrm{d}$ in the city of Brunswick and an increase in withdrawal of $9 \mathrm{Mgal} / \mathrm{d}$ northwest of Brunswick near Anguilla was simulated to assess the possible effects of moving the municipal water supply for metropolitan Brunswick away from the center of the city, where saltwater intrusion has occurred, to an area where, at present (May 1985), there is no development. The net increase of 5.9 $\mathrm{Mgal} / \mathrm{d}$ represents a projected increase in demand for municipal public supply and for other uses.

The results of the simulation showed the formation of a new cone of depression at the proposed well field, and a maximum decline of $5.4 \mathrm{ft}$ at each of the two adjacent pumping grid blocks (fig. 7). However, simulation results also showed a slight increase in water level (less than $1 \mathrm{ft}$ ) in the Brunswick area (fig. 7). The results indicated that increased withdrawal in the area probably could occur without inducing more vertical leakage of saltwater at the known points of intrusion if reductions in withdrawal were made in the immediate area of saltwater intrusion.

\section{Increased Withdrawal near Meridian, McIntosh County}

A simulation was conducted to determine the effects on the water level in the city of Brunswick caused by a projected increase in withdrawal in southeast McIntosh County. A withdrawal of $10 \mathrm{Mgal} / \mathrm{d}$ near the town of Meridian was simulated as an example of developing an additional ground-water source for multipurpose uses along that part of the coast. The maximum water-level decline was about $11 \mathrm{ft}$ at the pumping grid block. Figure 8 illustrates the simulated water-level change resulting from the increased withdrawal. The decline in the Brunswick area would be between 1 and $2 \mathrm{ft}$. 


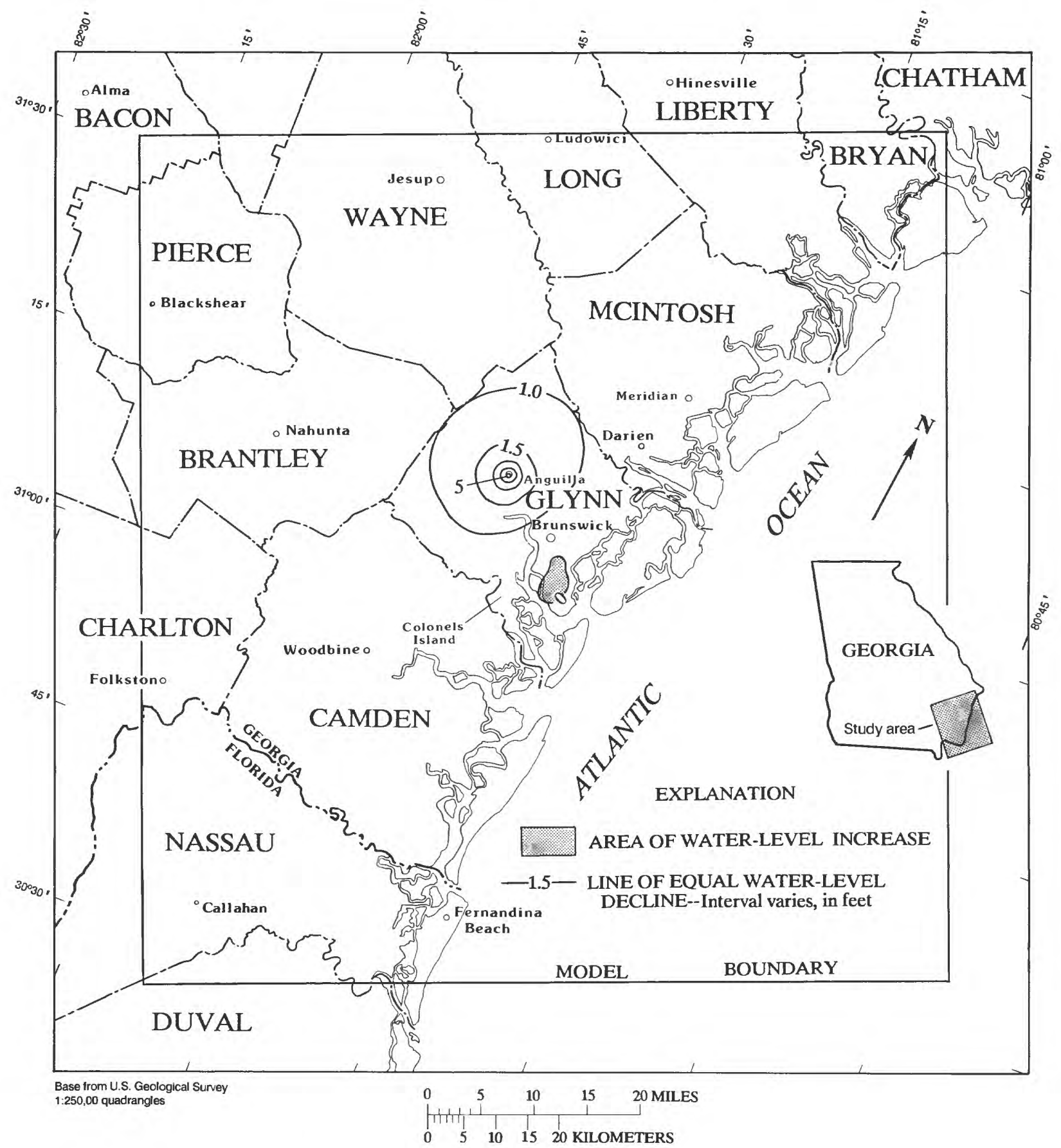

Figure 7.--Simulated water-level change caused by a decrease of 3 million gallons per day in withdrawal at Brunswick and an increase of 9 million gallons per day in withdrawal near Anguilla, Glynn County. 


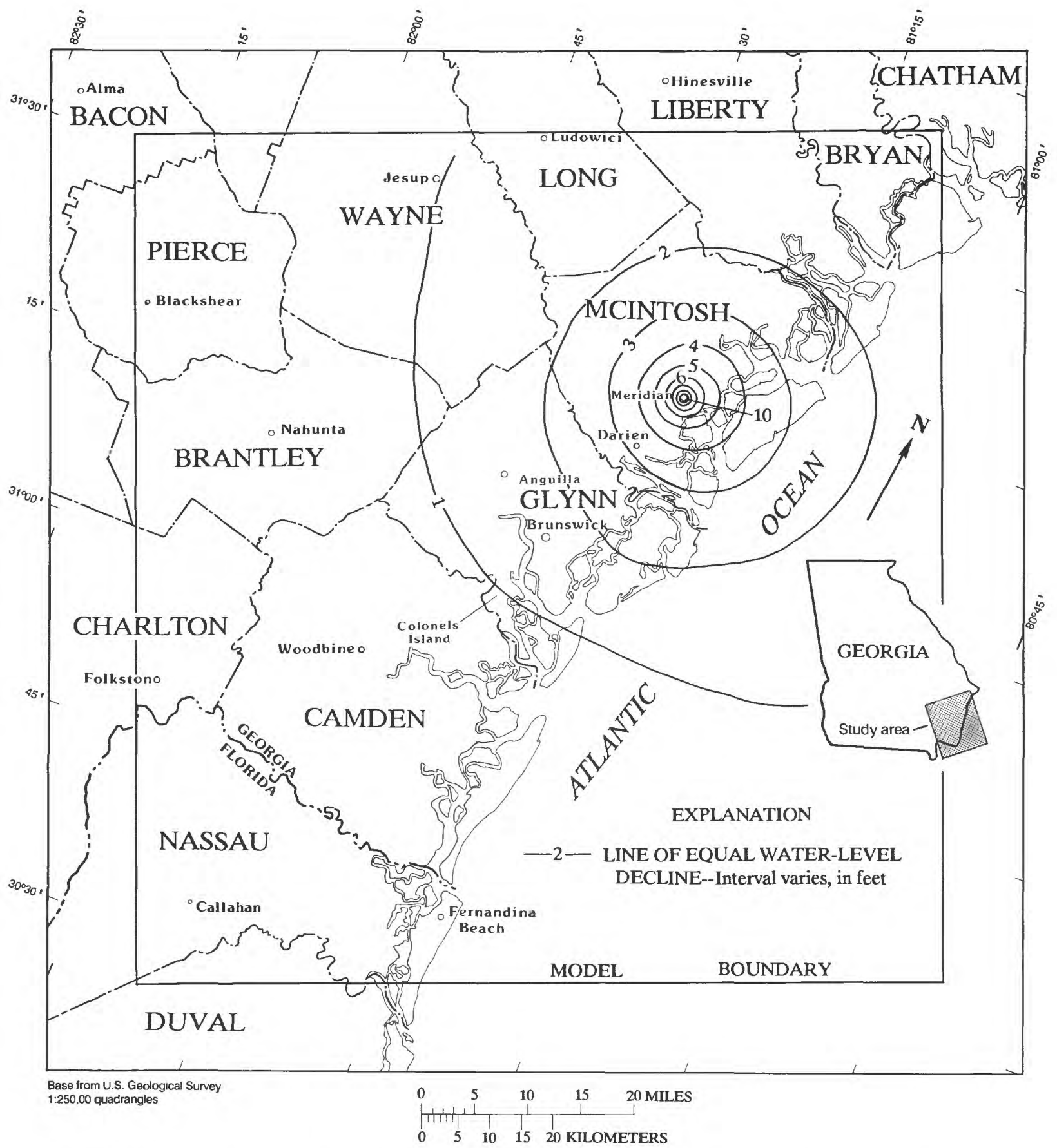

Figure 8.--Simulated water-level decline caused by a withdrawal of 10 million gallons per dav near Meridian, McIntosh County. 


\section{SUMMARY AND CONCLUSIONS}

Development of the Floridan aquifer system in the area of Glynn County, Ga., over the last century has resulted in large changes in flow patterns. Prior to development, flow in the study area was sluggish and was toward the sea; the total flow through the area was about $74 \mathrm{Mgal} / \mathrm{d}$. The May 1980 flow system was dominated by a cone of depression in the Brunswick area, and by large lateral and vertical changes in flow direction. Although the total flow through the area in May 1980 was approximately $324 \mathrm{Mgal} / \mathrm{d}$, the system still exhibited the properties of a steady-state flow regime.

The Floridan aquifer system in the Glynn County area was simulated by using a coupled-model approach. The finely gridded, Glynn County model was developed for use with an existing, coarsely-gridded model of the Floridan covering the entire coast of Georgia and adjacent parts of Florida and South Carolina (the RASA model). The quasithree-dimensional, finite-difference model was designed to offer the greatest detail in the area of Glynn County where large withdrawal and saltwater intrusion are problems.

The refined grid of the Glynn County model is aligned with the coarse grid of the regional model and each grid block is a division of the coarse-grid blocks. The refined grid is variably spaced, having the smallest grid blocks and the greatest detail in the areas of large withdrawal and saltwater intrusion. Boundary flows for the Glynn County model are derived from the large-scale regional model.

Initial calibration of the Glynn County model was accomplished by using the potentiometric surfaces and the hydraulic characteristics of the ground-water flow system as they existed prior to development in about 1880. The model then was calibrated independently using the potentiometric surface and the ground-water flow system of May 1980 by using a steady-state simulation under pumping conditions. Calibrated aquifer parameters were compared with those in the RASA model until an agreement was reached between the two models. The May 1985 ground-water flow conditions and potentiometric surface then were simulated to verify the accuracy of the calibration and to further refine estimates of input parameters.

Three hypothetical changes in ground-water withdrawal were simulated to illustrate application of the model. First, a simulated $10-\mathrm{Mgal} / \mathrm{d}$ increase in withdrawal on Colonels Island resulted in a water-level decline of 2 to $3 \mathrm{ft}$ in Brunswick, in the area of known saltwater intrusion. Second, a simulated increase in withdrawal for a municipal water supply for Brunswick northwest of the city and the decrease in public supply pumpage in Brunswick resulted in a slight increase in water level inside the city of Brunswick, and a maximum decline of $5.4 \mathrm{ft}$ at the new well field northwest of the city. Finally, an increase in withdrawal of $10 \mathrm{Mgal} / \mathrm{d}$ in southeast McIntosh County near the town of Meridian resulted in a water-level decline between 1 and $2 \mathrm{ft}$ at the center of the city of Brunswick, and a maximum decline of about $11 \mathrm{ft}$ at the new well field. 


\section{REFERENCES}

Brown, D.P., 1984, Impact of development on availability and quality of ground-water in eastern Nassau County, Florida, and southeastern Camden County, Georgia: U.S. Geological Survey Water-Resources Investigations Report 83-4190, 113 p.

Clarke, J.S., 1987, Potentiometric surface of the Upper Floridan aquifer in Georgia, May 1985, and water-level trends: Georgia Geologic Survey Hydrologic Atlas 16, 1 sheet, 1:500,000.

Clarke, J.S., Hacke, C.M., and Peck, M.F., 1990, Geology and ground-water resources of the coastal area of Georgia: Georgia Geologic Survey Bulletin 113, 106 p.

Gregg, D.O., and Zimmerman, E.A., 1974, Geologic and hydrologic control of chloride contamination in aquifers at Brunswick, Glynn County, Georgia: U.S. Geological Survey Water-Supply Paper 2029-D, 44 p.

Johnston, R.H., Krause, R.E., Meyer, F.W., Ryder, P.D., Tibbals, C.H., and Hunn, J.D., 1980, Estimated potentiometric surface for the Tertiary limestone aquifer system, Southeastern United States, prior to development: U.S. Geological Survey OpenFile Report 80-406, 1 sheet, 1:1,000,000.

Johnston, R.H., Healy, H.G., and Hayes, L.R., 1981, Potentiometric surface of the Tertiary limestone aquifer system, Southeastern United States, May, 1980: U.S. Geological Survey Open-File Report 81-486, 1 sheet, 1:1,000,000.

Krause, R.E., 1982, Digital model evaluation of the predevelopment flow system of the Tertiary limestone aquifer, southeast Georgia, northeast Florida and southern South Carolina: U.S. Geological Survey Water-Resources Investigations Report 82-173, $27 \mathrm{p}$.

Krause, R.E., and Counts, H.B., 1975, Digital model analysis of the principal artesian aquifer, Glynn County, Georgia: U.S. Geological Survey Water Resources Investigations Report 1-75, 4 sheets.

Krause, R.E., and Randolph, R.B., 1989, Hydrology of the Floridan aquifer system in southeast Georgia and adjacent parts of Florida and South Carolina: U.S. Geological Survey Professional Paper 1403-D, 65 p.

Marella, Richard, 1986, Annual water use survey: 1985: St Johns River Water Management District Technical Publication SJ 86-5, 117 p.

Maslia, M.L., 1987, Regional and local tensor components of a fractured carbonate aquifer, in Farmer, I.W., and others, eds., Rock Mechanics: Proceedings of the 28th U.S. Symposium, University of Arizona, Tucson: Boston, A.A. Bulkema, p. 441-452.

Maslia, M.L., and Prowell, D.C., 1990, Effect of faults on fluid flow and chloride contamination in a carbonate aquifer system: Journal of Hydrology, v. 115, nos. 1-4, p. $1-49$.

McDonald, M.G., and Harbaugh, A.W., 1984, A modular three-dimensional finitedifference ground-water flow model: U.S. Geological Survey Techniques of WaterResources Investigations, bookk 6, chapter A-1, 586 p. $875,528 \mathrm{p}$. 


\section{REFERENCES--Continued}

Miller, J.A., 1986, Hydrogeologic framework of the Floridan aquifer system in Florida and in parts of Georgia, South Carolina, and Alabama: U.S. Geological Survey Professional Paper 1403-B, 91 p.

Pierce, R.R., Barber, N.L., and Stiles, H.R., 1982, Water use in Georgia by county for 1980: Georgia Geologic Survey Information Circular 59, 180 p.

Randolph, R.B., Krause, R.E., and Maslia, M.L., 1985, Comparison of aquifer characteristics derived from local and regional aquifer tests: Ground Water, v. 23, no. 3, p. 309-316.

Stone, H.L., 1968, Iterative solution of implicit approximations of multidimensional partial differential equations: Society for Industrial and Applied Mathematics, Journal for Numerical Analysis, v. 5, no. 3, p. 530-538.

Wait, R.L., 1965, Geology and occurrence of fresh and brackish water in Glynn County, Georgia: U.S. Geological Survey Water-Supply Paper 1613-E, 94 p.

Wait, R.L., and Gregg, D.O., 1973, Hydrology and chloride contamination of the principal artesian aquifer in Glynn County, Georgia: Georgia Department of Natural Resources Hydrologic Report 1, 93 p.

Weinstein, H.C., Stone, H.L., and Kwan, T.V., 1969, Iterative procedure for solution of systems of parabolic and elliptic equations in three dimensions: Industrial Engineering Chemistry Fundamentals, v. 8, no. 2, p. 281-287. 